\title{
Misbelief, \\ Marlovian Promises, and Planets
}

\section{GERGŐ DÁVID}

Abstract: The paper argues that Marlowe presents a sceptical worldview on religious and social conduct in his plays. However, his scepticism does not affect his viewes of the natural world, which is represented by the planetary influences. The ability to exert one's will over the world is called into question and substituted by the deterministic power of the planets. The paper is concerned with the idea of promises in terms of human interaction from various perspectives, such as religious and political points of view. Both religious and secular promises are either void or turn on themselves. In my reading of Marlowe's plays (The Jew of Malta, Doctor Faustus, Tamburlaine Parts I and II), notions of promises and scepticism are strongly intertwined, which might help us understand why Marlowe's works are seen as the products of a cynical mind with atheistic traits.

Virtually all critical work on Christopher Marlowe mentions his atheism, subversiveness and strange sense of humour. His alleged atheism is usually discussed in connection with Richard Baines' infamous letter, Thomas Kyd's extorted accusations, and his cruel and/or defiant characters, such as Tamburlaine, Faustus and Barabas. However, "atheism" is a slippery term: as David Riggs convincingly argues, atheists in Marlowe's time were those "who rejected the immortality of the soul, the existence of heaven and hell, and the operations of Providence" (46). Marlowe's characters seem to have an ambiguous relationship with all of these, and Baines' letter also suggests dissent from contemporary orthodox beliefs, even though it is very likely to have been written in bad faith: since his protagonist died under very dubious circumstances, it was in his best interest to make a scapegoat of Marlowe, whom no one should pity or mourn. Marlowe's subversiveness is also 


\section{GERGÖ DÁVID}

often paired with theories about his supposed homosexuality and it is examined with respect to his surprisingly sympathetic treatment of Edward II or his apparent obsession with characters who turn social norms and conventions upside down. Marlowe seems to be a playwright who resists easy categorisation and his sense of humour serves as useful illustration for that. He has been described as a "writer singularly devoid of humour" (Dowden 108), as a person with no "particle of real humour in him" (Hudson 115), and according to some, a sense of humour was definitely not his "strong point" (Ward 119), and when it is still granted, it is often described as "coarse" ("Unsigned Article" 191), "scatological” (Hopkins 107), "mordant" (Honan 274), or "sardonic" (Deats 195). The varied perceptions of his sense of humour serve as indicators of his mixture of comic and tragic genres, but also of his mocking treatment of serious subjects. This paper claims that these observations are not without justification and the impression that Marlowe scholars get has to do with the playwright's treatment of free will, which stems from a basically sceptical attitude and pervades Marlowe's oeuvre. It is this Marlovian scepticism - sometimes infused even with cynicism - that seems to reinforce our notions about Marlowe being a subversive atheist with a derisive sense of humour.

Firstly, I shall clarify how the terms scepticism and misbelief are used here. Marlovian scepticism seems to me a mixture of Pyrrhonian scepticism, characterised by anti-dogmatism and the suspension of judgement concerning knowledge, and modern scepticism, understood as "thoroughgoing doubt about unproven and especially nonmaterial claims" (Lehrich 75). Dramas usually investigate cultural values, language, and how these relate to social practice as well as reality. However, Pyrrhonian scepticism's tendency to suspend judgement is not present in all the plays of the period. Marlowe's plays are different in this respect, because Pyrrhonian seems to be an adjective applicable to him and all his plays. However, Pyrrhonism leaves ample space for beliefs which Marlowe also questions in his plays. ${ }^{1}$ From this questioning stems our perception of him as an atheist. ${ }^{2}$ Similarly to his sense of humour, his scepticism and atheism are impossible to fit into a single unified category, since they are essentially mixed and do not always necessitate the complete lack of beliefs - either in a spiritual sense or in a practical sense (that is, believing others).

1 According to Christopher Lehrich, "many Renaissance sceptics can be labelled "fideists" (75). Therefore, while Renaissance scepticism is not incompatible with fideism, Marlowe's scepticism is.

2 As Michael Hunter claims, "atheism" was used in a variety of ways, from denoting a disbeliever in the modern sense to someone who did not conform to the beliefs held by a given community 


\section{MISBELIEF, MARLOVIAN PROMISES, AND PLANETS}

Marlowe's scepticism can be observed in relation to three major topics: religion, politics and social conduct. When these topics emerge in Marlowe's texts, one has to realise that they are often treated in key dramatic situations in which promises are made by misbelieving - often sceptical and cynical — characters. "Misbelief" in this essay is understood as misplaced and/or erroneous belief. Being in a state of misbelief with respect to promises is also a prevalent feature of Marlowe's plays. The title of this essay suggests that promises are treated in some special way by Marlowe, hence the adjective Marlovian. My understanding of a Marlovian promise is quite simple: it is a promise not intended to be kept and one which ironically turns into its own parody. ${ }^{3}$ Calling this kind of promise Marlovian is justified by the large number of such promises. J. L. Austin, the father of speech-act theory, called promises similar to these "hollow," and the act of promising is considered to be a case of "abuse," as opposed to cases when I am, for example, not in a position to promise at all. In the latter cases, the promise "misfires" and it is "void," "empty," "without effect" (Austin 16). We must see that in the case of Marlovian "hollow" promises, the one who promises - in Austin's words - “does promise: the promise here is not even void, though it is given in bad faith. His [the person's, her] utterance is perhaps misleading, probably deceitful and doubtless wrong, but it is not a lie or a misstatement (to the effect that he does intend to do something)" (Austin 11). What that "something" is remains equivocal until action backs up one of the meanings of that promise.

The word "misbelief" appears in The Jew of Malta three times in some form at crucial points. The term is attached to the protagonist Barabas himself, his daughter Abigail, and the Turks. In the first instance, Friar Jacomo confronts Barabas: "Barabas, although thou art in misbelief / And wilt not see thine own afflictions, / Yet let thy daughter be no longer blind" (1.2.353-355). ${ }^{4}$ From a Christian point of view, Barabas is a misbeliever, because he clearly acts on certain beliefs, but these beliefs are not what the Christians consider true. In this respect, the Friar is in double-misbelief,

(e.g. Catholics, Machiavellians, Epicureans, or even Elizabeth I), that is, atheism might have been a simple term of abuse or a serious theological charge. The widely recognised characteristics of atheists are also applicable to Marlowe and his characters: openly promoting atheism by questioning orthodox views, scornfulness, scepticism, Machiavellianism, anti-clericalism, just to mention a few.

3 For example, Faustus misbelieves that magic can promise earthly riches and glory, and to his immense dissatisfaction they only guarantee exactly that and not what he really needs. In the final scene of The Jew of Malta, Barabas believes Ferneze's equivocal "Take what I promised thee" and is killed by his own device.

4 All quotations from Marlowe's plays are from Christopher Marlowe, Doctor Faustus and Other Plays. 


\section{GERGÖ DÁVID}

because Barabas believes in exactly what the Friars turn out to be after - money. Marlowe seems to efface the differences between Christian and Jew, which points to religious relativism - and potentially the kind of broad sense of atheism mentioned earlier. However, the Friar is also in misbelief in a more practical sense concerning both Abigail and Barabas, who happen to deceive him in that very moment. Even though he calls attention to the blindness of Abigail, he does not recognise his own blindness, which is one of the many ironic occurrences in the play that lay the foundation for the notion of Marlowe's sardonic humour. The second occurrence of the word "misbelief" appears when Ferneze breaks his promise to those "barbarous, misbelieving Turks" (2.2.45). Here, too, the word is used to justify the speaker's hostility towards the Other. Furthermore, Barabas and the Turks are linked together through the same concept, which is not accidental, since Jews and Turks were rumoured to be financially complicit (Siemon ix). Misbelief appears for the third time in a remarkably different context, because now it is Abigail who calls herself a misbeliever: "My sinful soul, alas, hath paced too long / The fatal labyrinth of misbelief, / Far from the Son that gives eternal life" (3.3.63-65). The difference is twofold: on the one hand, stylistically, it appears in a more poetic form (loaded with vivid imagery of the separation of light and darkness) than the previous two, which evokes sympathy towards the speaker as the audience gains insight to her inner conflict. On the other hand, the word is used by the speaker to describe herself, which distinguishes her from the other characters, who cannot recognise their own misbeliefs. With the help of these differences, Abigail is elevated above the rest of the characters. However, before we mistakenly slip into idealizing her, it should be mentioned that she remains complicit with her father's previous actions by concealing them - only her impending death prompts her to reveal some of the truth - and by withholding the Christian virtue of forgiveness. The contents of the letter are not revealed to the audience, but it is quite probable that she does not fully reveal her own part in stealing the money. The Friars seem to learn about Barabas' wealth when they confront him, so Abigail might have remained silent about her involvement in those matters. Even her conversion falls under suspicion since it does not issue from genuine belief but from her disappointment in everyone else ("I perceive there is no love on earth, / Pity in Jews, nor piety in Turks" [3.3.47-48]); it can be taken as her revenge on her father. To emphasise the ambiguity around her, we might even hear 


\section{MISBELIEF, MARLOVIAN PROMISES, AND PLANETS}

a slightly distorted "beguile" in her name. ${ }^{5}$ Her name elicits further irony, as it means “the father's joy." Once again, we witness Marlowe using his frequently employed strategy of effacing differences between religious denominations - here Christians and Jews - by showing a quasi-virtuous Jew joining the hypocritical Christians.

Misbelief serves as an indicator of different factions that treat each other with contempt. However, misbelief also gives rise to scepticism, since it is obvious that the Other - who is apparently in misbelief from the perspective of one faction - might share different values and convictions. ${ }^{6}$ Therefore, the Others - in this case the Jew and the Turks - are a potential threat. When Abigail renounces her faith, she becomes a misbeliever from Barabas' perspective and turns into a source of danger for him: "For she that varies from me in belief / Gives great presumption that she loves me not" (2.4.10-11). This passage shows that her religious conversion translates into other domains of everyday life, notably that of the father-daughter relationship, which implicitly challenges patriarchal authority. Now we can see a stereotypical Marlovian feature: the defiance of social norms presented in a way that amuses and captivates the audience, thus turning them into accomplices - even if they disapprove of the transgressive action. ${ }^{7}$

Marlowe also battles current social norms on another front. He undermines the belief in the power of words by making all his characters break their promises. The first time a promise is mentioned in the play, it has to do with religion:

Thus trolls our fortune in by land and sea,

And thus we on every side are enriched.

These are the blessings promised to the Jews,

And herein was old Abram's happiness. (1.1.101-104)

Unsurprisingly, the religious promise mentioned by the Jew is conceptually connected to material riches and treasure. It seems more than an early modern stereotype

5 I am grateful for this suggestion to Professor Tzachi Zamir. The modern pronunciation of the name is not very far from the early modern pronunciation of "beguile" /bi'gərl/ as given by David Crystal (51).

6 These values and conventions are always suspect from an outsider's perspective; however, the dramatic form encourages the audience to examine their own sets of beliefs. In the atmosphere of early modern England, ridden with political and social anxieties, the questioning of the conventional social norms and values might be taken as a further example of Marlowe's subversiveness.

7 Although Abigail's conversion is darkened by the aforementioned reasons, it probably seems virtuous to a modern audience. However, disobeying the patriarch was considered to be a more serious 


\section{GERGÖ DÁVID}

about the covetous Jew; religion is presented with materialism side by side from the very beginning and, therefore, it is shown to be a hypocritical institution. Not only are the Jews and Turks ridiculed but also the Christians. In addition to Ferneze's overall Machiavellian policies, the whole of Christianity is discovered to be a scheming political institution by no other than Machiavelli himself: "Though some speak openly against my books, / Yet will they read me and thereby attain / To Peter's chair" (Prologue 10-12). The honesty of the nuns and the humility and simplicity of the friars are also called into question throughout the play. It seems that there is no place for genuine belief or trust in Marlowe's Malta. Trust is undermined early on in the play:

\footnotetext{
It is no sin to deceive a Christian,

For they themselves hold it a principle

Faith is not to be held with heretics.

But all are heretics that are not Jews. (2.3.310-313)
}

Even though these are the words of Barabas, they contain the opinion of the Christians who seem to act according to this principle in their dealings with the Turks. ${ }^{8}$

With broken promises, misplaced belief in religion and hypocritical social conduct - the symptoms of a world in crisis and of Marlovian scepticism - it is difficult to find reassurance, stability and fixed points to which one could cling. The underlying reason for the instability of these concepts is their strong reliance on monetary value. Barabas' belief is based on the divine promise of treasures, his love for Abigail manifests itself in her ability to take back his wealth, Ferneze's promises always involve some kind of payment (the tribute to the Turks, the bag of money offered to Barabas in the last act), and Lodowick identifies Abigail with a diamond which can be bought or sold, like a slave at the market. Concepts, ideas, feelings, even people may be given a price tag, which is best exemplified by Barabas' joyful exclamations when Abigail throws his treasures out of the window:

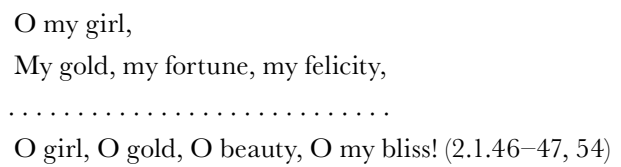

transgressive act - similar to treason on a domestic scale - at the time.

8 The same principle is followed by the Christians in Tamburlaine The Great, Part II, 2.1.33-41. 


\section{MISBELIEF, MARLOVIAN PROMISES, AND PLANETS}

However, as money changes hands, these values are deflated by the exchange itself, thus they become unstable and fluctuating. The didactic and orthodox moral is that believing in promises made over monetary transactions is misbelief with tragic results. However, true to the Marlovian sentiment, there is no alternative moral framework offered. Ferneze wins the game not because he has the moral high ground but because he is the more successful Machiavel and his final hypocritical moralisation - "let due praise be given / Neither to fate nor fortune, but to heaven" (5.5.122-123) — identifies him as the Prologue's Machiavel.

A similarly unstable world is shown in Doctor Faustus. At the beginning of the play, a similar promise is introduced: " $\mathrm{O}$, what a world of profit and delight, / Of power, of honour, of omnipotence / Is promised to the studious artisan!" (1.1.55-57). Like in The Jew of Malta, the idea of a promise is associated with earthly pleasures, such as power, honour, profit and delight. However, this play sounds the depth of another matter. Whereas The Jew focused on these as strictly material, fiscal aspects of promises, Faustus is more concerned with intellectual self-prostitution and - more importantly from our point of view - religious promises. Although Barabas mentions the Biblical promise to "old Abram," the vast majority of the promises in The Fer is made by people. In Faustus, the promises are not made by anyone, rather Faustus takes those promises granted by magic or by Mephistopheles.

In The Jew of Malta we have already seen Marlowe pointing out the fissures in society and its hypocritical practice as strategies inherent to politicised religion. In Faustus, however, an even more overtly sceptical voice is heard. First of all, supernatural agency is represented as an oppressive, malicious power. The Prologue's famous lines allude to the malevolent nature of the heavens: "And melting heavens conspired his overthrow" (22). However, it is important to note that the heavens might not mean the Christian heaven but the celestial spheres. Thus, Marlowe obscures the difference between the religious and the astronomical, proto-scientific concepts. Later on, it becomes clear that Faustus is determined to fall: the "stars that reigned at [his] nativity, / Whose influence hath allotted death and hell" (5.2.81-82) for him are responsible for his downfall and not only is he conspired against, but he also tries to further his own damnation. Benevolent divine agency is notably under-represented in the play: the only good characters seem powerless and are not heeded by Faustus, since he fails to listen to the Good Angel. The Old Man's advice is also ignored. Divine agency is presented as a Machiavellian force engaged in a contest for Faustus' soul that seems to be a matter of supernatural warfare for power. 


\section{GERGÖ DÁVID}

Strictly speaking, what is at stake is not Faustus' bliss but his worth as an addition to the kingdom of either God or Lucifer. It is explicitly revealed by Mephistopheles that Lucifer's purpose in obtaining the soul of Faustus is to "[e]nlarge his kingdom" (2.1.40). The distinction between the spiritual and the secular realm disappears in the play.

The description of the relationship between Faustus and Mephistopheles highlights the ambiguous nature of their relationship in which it is unclear who the servant is. The pact ensures that Mephistopheles must serve Faustus, but it is apparent throughout the play that Mephistopheles is the master, primarily on the grounds that he is the one who can perform the tricks and "miracles." This ambiguity further obscures the issue of responsibility, that is, whether it is Faustus who is liable for his fate or outside forces. However, Marlowe's treatment of the subject is not entirely unique. A few years later, King James discusses the same conundrum in his Daemonologie: "How can that be true, yt any men being specially adicted to his [i.e. the Devil's] service, can be his commanders?" (bk. 2, ch. 3). This question about the contest for power might be rhetorical for James, but for Marlowe, such a mixture of raw political power and religion fits his cynical Machiavellian view on religion. The cynicism is further amplified with the introduction of bartering, as if transcendental values could be treated as commodities. Similarly, the mercantile nature of drawing a pact and exchanging one immaterial thing - a soul - for a material thing - earthly pleasures - is another trait similar to The few of Malta. Just as Barabas thinks that anything can be converted to money, Faustus holds that his soul might serve as a commodity which can be exchanged for anything - knowledge, power, treasures and love: both of them are in misbelief. However, Marlowe gives a further twist to the issue by presenting misbelief, again, as doubled. After all, since the deal is made, it is possible to exchange a soul for mere earthly pleasures. The deal is a bad one for Faustus, but the fact that it is possible further diminishes the distinction between the spiritual and the earthly.

Both heaven and hell are depicted as places strongly resembling the world in which Faustus lives and the otherworld becomes nearly indistinguishable from the magician's world. Heaven is described as a place which "was made for man" (2.3.9-10) and both possible interpretations of the ambivalent references to hell suggest that Faustus is already in hell. Mephistopheles' words"Hell hath no limits, nor is circumscribed/In one self place, for where we are is hell, / And where hell is must we ever be" (2.1.121-123) - suggest a psychological 
interpretation of hell as a state of mind rather than a geographical location. However, the first person plural sounds as if Mephistopheles were already including himself and Faustus in hell, thus implying that Faustus is already in hell together with Mephistopheles. It would mean that hell is on Earth, but this seems absurd to Faustus and he calls it into question ("How? Now in hell? / Nay, and this be hell, I'll willingly be damned here. / What? Walking, disputing, etc.?" [2.1.128-139]).

With external conditions being so overwhelmingly powerful, it is logical to accept his damnation as a result of predestination, since the Prologue's deterministic approach and his final tragic recognition that the stars reigning at his nativity doomed him confirm the idea. Whether these stars signify the heaven of the Christian God or the heavens of the astronomers, in either case, a Christian audience should feel uneasy and reflect on their (mis)beliefs. If the stars serve as the metaphor for God or the manifestation of his will in nature, then it means the complete lack of one's agency over one's fate. If the stars simply mean planets that can control one's humoral constitution, then it is possible - with strong willpower - to counteract these forces; however, this interpretation eliminates - or at the very least ignores - the necessity of God and Divine Providence.

The evidence suggesting the deterministic power of celestial influences is present in some of Marlowe's other works as well. Most prominent of all are the Tamburlaine plays. Before the discussion of Tamburlaine, however, we should turn to the issue of celestial bodies. One literary example reflecting on the nature of astrology is King James' Daemonologie, which calls attention to the pitfalls of this branch of science. He posits that astrology can be divided into two parts: lawful and unlawful. Lawful astrology describes the course of seasons, the weather, the planetary influence on diseases and the motions of the planets. Unlawful astrology, however, stems from trusting "so much to their influences, as thereby to fore-tell what common-weales shall florish or decay: what persones shall be fortunate or vnfortunate," and Christians are forbidden "to beleeue or hearken vnto them that Prophecies \& fore-speakes by the course of the Planets \& Starres" (bk. 1, ch. 4). In my reading, Marlowe voices an opinion which states the opposite, yet again, voicing a potentially subversive point of view, and further obscures the roles of free will, Providence, and nature.

As we have already seen, the heavens and the stars condemn Faustus; he is destined - yet due to his excessive pride also determined - to fall. The promises made 


\section{GERGÖ DÁVID}

by Mephistopheles and Lucifer always fall short. ${ }^{9}$ Despite Faustus' protestations, he cannot stop the "ever-moving spheres of heaven" (5.2.60). A similar recognition - which also comes too late - is discovered by Abigail in The Jew of Malta: "My sinful soul, alas, hath paced too long / The fatal labyrinth of misbelief, / Far from the Son that gives eternal life" (3.3.63-65, emphasis added). Aside from the fact that son is a homophone of Sun, the context also allows association with the star. After all, the labyrinth was built by Icarus' father who instructed his son not to fly too close to the Sun. However, he was also instructed not to fly too far from it, lest he gets caught in the waves. The Icarian imagery also relates her to Faustus, the crucial difference is that Abigail descends too low, while Faustus attempts to ascend too high. ${ }^{10}$ Barabas also curses his own "fatal birthday" (1.2.193), the "partial heavens" (261), and the "luckless stars" (260) which oppose him. I do not mean to deny the differences in morality between Faustus, Abigail, and Barabas: Faustus and Abigail recognise their own sins, Barabas does not. They, however, share the same position in the sense of being unable to alter their fate. The fact that their fate is presented through planetary influences and not solely by concepts of Christian morality suggests a sense of predestination by natural forces rather than God. The only character who reckons with the heavenly spheres instead of opposing them is Tamburlaine.

When Tamburlaine appears, we see him talking to Zenocrate and describing his future empire in terms of a classical reference to the Sun: "Measuring the limits of his empery / By east and west as Phoebus doth his course" (Part I 1.2.38-39). Through this imagery, Tamburlaine shows that he recognises the limiting powers of celestial bodies that encompass his empire, but at the same time, he is also undaunted by them. Tamburlaine trusts the heavenly powers and often identifies himself with them. His tenets deny what later King James writes about in his Daemonologie because Tamburlaine claims: "fates and oracles of heaven have sworn / To royalise the deeds of Tamburlaine" (Part I 2.3.6-7). In contrast with Faustus, Tamburlaine finds hope and assurance in the "stars that reigned at [his] nativity" (Part I 4.2.33), because his "smiling stars gives him assuréd hope" (Part I 3.3.41-42). At the same time, the play resembles both Doctor Faustus and The Jew of Malta in its treatment of Christians as hypocrites.

9 Even the promise of damnation is deceptive, since it is not in the power of Lucifer or Mephistopheles to damn Faustus. Faustus is promised something he would receive anyway. The underlying belief that one can further one's damnation is also presented as misbelief.

10 In Faustus, the image of Icarus is evoked in the Prologue with the heavens "melting" his "waxen wings" (21-22). 
Frederick advises Sigismond to break his Christ-sanctified oath about the truce with the Turks: "Assure your grace 'tis superstition / To stand so strictly on dispensive faith" (Part II 2.1.49-50). However, religion is derided in Marlowe's works as "but a childish toy" (Prologue 14) in The few; in Faustus, hell is just a "fable" (2.1.127), and questions about men's souls are just "vain trifles" (1.3.62). Faustus "confounds hell in Elysium" (1.3.60), but in the Marlovian world, hell seems to be confounded in heaven: "hell hath no limits, nor is circumscribed / In one self place" (2.1.120-121), says Mephistopheles, as it has been mentioned previously. However, Orcanes, King of Natolia and enemy of Tamburlaine, describes God with strikingly similar imagery:

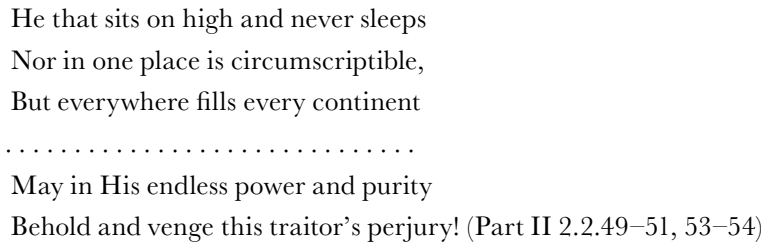

By presenting God and Hell in the same terms, Marlowe risks atheism. Even though the Christians are defeated, divine intervention seems to be absent, since Orcanes invokes every major divine influence, including Christ, God, Mahomet, and Jove, which empties out the referents of these names and makes them sound insignificant. The absence of divine retribution is further highlighted in Tamburlaine: despite the fact that Tamburlaine feels "distempered" after burning holy books, the last scene makes it clear that the cause of his illness is a lack of natural heat and humidity. Such imbalances in the bodily humours could have been influenced by the planets and the doctor points out that "this day is critical" (Part II 5.3.91), that is, astrologically disadvantageous. Once again, it seems that the planetary influences have the most prominent effect on the protagonists' lives.

Thus, in the final analysis, it seems that in the Tamburlaine plays, just as much as in The Jew of Malta and Doctor Faustus, the fate of the respective protagonists is sealed from the beginning by planetary influences. However, Tamburlaine's death is remarkably different from the death of Faustus and Barabas. The Jew and the scholar die desperate and miserable without the hope of salvation. Not accidentally, they are also blind to planetary influences that govern their lives. 


\title{
GERGŐ DÁVID
}

Barabas misbelieves in a divine promise of riches and Christian ethics. ${ }^{11}$ Faustus is also in misbelief when thinking that he possesses the free will to bring about his own damnation. Tamburlaine, however, seems to reckon with the powers of the stars from the very beginning. He is the only protagonist who has enough time to care for his own funeral, to appoint an heir and to say goodbye to his family and friends. More importantly, he is the only one dignified enough to die without cursing, struggling, or bargaining for one more hour. Furthermore, he even hints at his own immortality:

\author{
But sons, this subject, not of force enough \\ To hold the fiery spirit it contains, \\ Must part, imparting his impressions \\ By equal portions into both your breasts; \\ My flesh, divided in your precious shapes, \\ Shall still retain my spirit though I die, \\ And live in all your seeds immortally. (Part II 5.3.168-174)
}

It is unsurprisingly Marlovian that a warrior with probably the highest deathcount deserves the most peaceful and dignified death. ${ }^{12}$ In a world where human action is governed or thwarted by inaccessible non-anthropomorphic powers, the commonplace wishful thinking, which claims that everyone deserves according to his merit, is impossible - it may even be ridiculously naïve.

The imagery concerning the dominance of celestial bodies and their influence underlines the contrast between the oppressive force of the heavens on the one hand and the insignificance and weakness of human action and free will on the other. The turbulent and unstable human domain seems chaotic and the characters inhabiting this world are fragile and mutable. They live their lives in a state of misbelief, thinking that they can exert their will upon the outside world. In contrast, the planets exert an immutable deterministic influence on these tragic heroes,

11 Alan Warren Friedman characterises Barabas as selfish, naïve, and conservative. In his reading, "Barabas returns the governorship to Ferneze's corruption and misrule because of his continuing, childishly naïve trust in Ferneze as embodying social authority and true Christian morality, his conservative hope of restoring the old order and his need to return to the inner-directed, selfish life he knew at the play's beginning" (158).

12 Warren D. Smith claims that Tamburlaine is not the amoral and bloodthirsty villain he is generally perceived to be. Smith also cites examples of the hero's magnanimity and chivalry. Furthermore, Smith asserts that Tamburlaine could have been perceived with sympathy on the stage as "a fully acceptable hero to the Elizabethan audience" (160). 
two of whom - Faustus and Barabas - try to counter these powers but their struggle is futile. Marlowe's plays show that the human condition is essentially tragic and that the only way to find redemption - like in the case of Abigail and Tamburlaine - is to recognise these tragic limitations and to bear them with dignity. The Marlovian "world-view" is sceptical about the potency of human actions and might be deemed deterministic, naturalistic, or fatalistic - or somewhere along these lines. Therefore, seeing Marlowe as a kind of atheist, who discards an anthropomorphic, benevolent deity in favour of a chaotic world governed by an impenetrable, natural, yet neutral force, is justified.

\section{Works Gited}

Austin, J. L. How To Do Things With Words. London, Oxford, New York: Oxford University Press, 1962.

Crystal, David. The Oxford Dictionary of Original Shakespearean Pronunciation. Oxford: Oxford University Press, 2016.

Deats, Sara Munson. "Dido Queen of Carthage and The Massacre at Paris." In

The Cambridge Companion to Christopher Marlowe. Ed. Cheney, Patrick. Cambridge:

Cambridge University Press, 2004. 193-206.

Dowden, Edward. "Transcripts and Studies." 1888. In Christopher Marlowe: The

Critical Heritage. Ed. MacLure, Millar. London, Boston, and Henley: Routledge and Kegan Paul, 1979. 99-109.

Friedman, Alan Warren. "The Shackling of Accidents in Marlowe's few of Malta." Texas Studies in Literature and Language 8.2 (1966): 155-167. Web.

Honan, Park. Christopher Marlowe: Poet E Spy. Oxford: Oxford University Press, 2005. Hopkins, Lisa. Christopher Marlowe, Renaissance Dramatist. Edinburgh: Edinburgh University Press, 2008.

Hudson, H. N. "Shakespeare: His Life, Art, and Characters." 1872. In: Christopher Marlowe: The Critical Heritage. Ed. MacLure, Millar. London, Boston, and Henley: Routledge and Kegan Paul, 1979. 112-116.

Hunter, Michael. "The Problem of 'Atheism' in Early Modern England.” Transactions of the Royal Historical Society 35 (1985): 135-137.

King James I. Daemonologie. 1597. Project Gutenberg. Project Gutenberg Literary Archive Foundation, 29 Jun 2008. Web. 27 Jan 2019.

Lehrich, Christopher I. The Language of Demons and Angels. Leiden: Brill, 2003. 


\section{GERGÖ DÁVID}

Marlowe, Christopher. Doctor Faustus and Other Plays. Eds. Bevington, David, and Eric Rasmussen. Oxford: Oxford University Press, 2008.

Riggs, David. “Marlowe's Quarrel with God.” In Critical Essays on Christopher Marlowe. Ed. Bartels, Emily C. New York: G.K. Hall; London: Prentice Hall International, 1997. 39-59.

Siemon, James R. Introduction. The Jew of Malta. By Christopher Marlowe. London: Bloomsbury Methuen Drama, 2009. vii-xxxii.

Smith, Warren D. "The Substance of Meaning in Tamburlaine Part I." Studies in Philology 67.2 (1970): 156-166. Web.

"Unsigned Article on Doctor Faustus." 1893. In: Christopher Marlowe: The Critical Heritage. Ed. Millar MacLure. London, Boston, and Henley: Routledge and Kegan Paul, 1979. 187-194.

Ward, A. W. "A History of English Dramatic Literature to the Death of Queen Anne." 1875. In: Christopher Marlowe: The Critical Heritage. Ed. MacLure, Millar. London, Boston, and Henley: Routledge and Kegan Paul, 1979. 118-121.

\section{Contributor Details}

Gergő Dávid is a doctoral student at Eötvös Loránd University, Budapest. He is a member of the Early Modern English Research Group (EMERG) and a coorganiser of the international conference Disbelieffrom the Renaissance to Romanticism (2017). He is currently writing his dissertation on the Marlovian influence on Shakespeare's plays. 